\begin{tabular}{c}
\hline Review of \\
ECONOMICS \\
and \\
INSTITUTIONS
\end{tabular}

\title{
Bringing in Liquidity and Transparency when the Power Sector is Consolidated: The Duty to Trade on the Power Exchange
}

\author{
Mariusz Swora \\ Independent researcher
}

\author{
Jacek Kamiński \\ Mineral and Energy Economy \\ Research Institute of the \\ Polish Academy of Sciences
}

\begin{abstract}
The paper discusses an energy policy instrument that was introduced in the power sector in order to reduce inefficient in-group electricity trading that was a source of soaring electricity prices. The remedy was especially tailored to correct the market failure that occurred in the Polish power market as a result of both: (i) the termination of Long Term Contracts and (ii) the governmentally steered consolidation of the power sector that also involved vertical integration. Several behavioural and structural instruments are considered and the reasoning supporting selection of the most appropriate one is given. The outcomes of qualitative analysis confirm that the remedy applied, namely the introduction of the PX duty to trade into the Polish Energy Law, was a successful market reform. The research carried out in this paper contributes to scientific knowledge on regulatory and policy issues and the solutions adopted can be considered as one of possible solutions of problems related to the lack of transparency and liquidity of power markets.
\end{abstract}

JEL classification: K23

Keywords: Market failure, transparency, power exchange

$\bowtie$ Address: Department of Policy and Strategic Research, Division of Energy Economics, Wybickiego Street 7A, 31-261 Kraków, Poland, tel. +48 126330296 Email: kaminski@min-pan.krakow.pl).

\section{Recommended Citation}

Swora, M., Kamiński, J., (2017). Bringing in Liquidity and Transparency when the Power Sector is Consolidated: The Duty to Trade on the Power Exchange. Review of Economics and Institutions, 8(1), Article 3. doi: 10.5202/rei.v8i1.248

Retrieved from http://www.rei.unipg.it/rei/article/view/248 


\section{Introduction}

Building common electricity and gas markets is the long term goal of the EU's liberalisation directives (2009/72, 2009/73). The main measures applied to achieve such goals are unbundling, Third Party Access (TPA) and transparency requirements. Execution of those tools is entrusted to a network of public bodies, consisting of the EC Commission, Agency for the Cooperation of Energy Regulators (ACER) and National Regulatory Authorities (NRAs) acting in cooperation with antitrust and financial authorities as well as central governments. It is of particular interest that legal instruments in the sector specific regulation of the electricity market are quite often borrowed from antitrust theory and practice. On the other hand, antitrust authorities sometimes cross the boundaries of competition law enforcement, using remedies that actively create (or even regulate) the markets. Our paper analyses a specific instrument, joining in its origin crosspieces of antitrust and sector specific regulation. The analysis of an instrument that we call duty to trade on the power exchange (hereinafter: PX duty to trade) is a contribution to the wider discussion on antitrust mechanisms and regulatory remedies such as Virtual Power Plant (VPP) auctions or electricity (gas) release programmes. We argue that although specific, the PX duty to trade belongs to the same family of pro-market remedies.

In the institutional dimension, the legal systems of Member States follow the EU liberalisation directives, regulating for measures that usually strictly implement those directives rather than using a method of regulatory innovation. However, every national or regional electricity market is characterised by specific unique features determined by historical, technical and economic factors, that should be taken into account by governments and NRAs, create the basis for regulatory innovation (of course within the goals of EU law) and thus adequately respond to the problems of particular markets. We believe that we have found and analysed specific market conditions that were the basis for adopting an innovative approach leading to achieving such a goal as a more liquid and transparent wholesale electricity market. That innovative approach has resulted in the adoption of a legislative instrument that was not explicitly listed among instruments available for NRAs in the EU market directives (2009/72/EC, 2009/73/EC), though as far as it leads to more transparency and liquidity of the wholesale market, it holds to the goals of these directives. In this respect, despite the specific market situation and solution we analyse, our article can be considered as an argument for an innovative approach to regulation and regulatory flexibility as a way of achieving a common electricity market. From the point of view of the EU energy policy, the subject of our analysis is important, as the duty to trade on the gas exchanges was a part of Polish proposal of so called the Energy Union. In this respect, our analysis may also contribute to a wider discussion on regulation of energy utilities in the EU law and policy. 
Insider (in-group) trading by vertically integrated energy companies is a common feature of energy markets. As far as transparency and liquidity of the market are concerned, such a situation is not desirable as it allows the generation of extraordinary profits and creates barriers to entry. Insider trading in monopolistic as well as in oligopolistic markets raises the question of the rationale of regulatory intervention. Responding to the serious competition restraints caused by insider trading, the regulator should have an opportunity to intervene using the regulatory tools available in order to intensify the liquidity of the market while not drastically restricting the choice of electricity market (bilateral, power exchange, balancing). In this respect regulatory powers should allow the regulator to respond proportionally with respect to specific market conditions. In our article, we analyse various legal tools with the intention of evaluating their appropriateness for responding to a situation of lack of liquidity and transparency in the wholesale electricity market.

Although the problem investigated in our paper has never been discussed in the international literature to the best of our knowledge, there have been many papers dealing with market reforms and the function of power exchanges. An interesting and up to date review on the lessons that could be drawn from the liberalisation of electricity markets in the context of the transition to a low carbon energy system was recently carried out by (Pollitt, 2012). As he also provides a concise outlook on the liberalisation processes, we deliberately omit this issue from our paper and kindly direct the reader to his paper where several references are also given.

As far as power exchanges, which are the focus of our paper, are concerned, (Singh, 2010) analysed the initial phase of power market reforms in the Indian energy sector focusing on the efforts undertaken to introduce a competitive wholesale and retail market. The paper also examined the role of traders and power exchanges in a market dominated by long-term contracts. (Meeus, 2011) addressed the problem of the regulation of power exchanges identifying two types of power exchange: (i) merchant and (ii) cost-of-service regulated. The Polish Power Exchange belongs to the first group. Arguable views on competitive trading in the spot market were developed by (Graf and Wozabal, 2013) who investigated the day-ahead market at one of the most important power exchanges in Central Europe, the EPEX. They applied the conjectural variations approach in order to analyse market power in the electricity market. (Nakajima, 2013) investigated the wholesale Japan Electric Power Exchange bringing attention to spot price formation on the exchange. (Meeus et al., 2009) discussed market coupling emphasizing the importance of price coordination between power exchanges in international wholesale trading arrangements. In the case of the Polish Power Exchange, detailed information on its regulation, trading rules and functioning can be found on the webpage: http://www.polpx.pl/en. Furthermore, one of the very few papers analysing day-ahead electricity prices on the Polish Power Exchange was carried out by (Bobinaite et al., 2013). Although (Bobinaite et al., 2013) paper investigates price developments, the issue of the introduction of new regulations was not 
considered. Therefore, our paper contributes to electricity regulation and the literature on policy with a strong emphasis on the impact of energy regulators on market design. Another crucial contribution of our paper is that it not only describes the theoretical aspects of correcting market failures, but it also discusses practical solutions based on the experience gained at the Energy Regulatory Office in Poland, which could be of use for other practitioners.

The power sector before electricity market re-design in 2009-2010 - the problem emerges

The Polish power industry has gone through a number of takeovers and mergers since the transformation that started in the late in 1980s. One of the first consolidations happened in 2000 - the government consolidated six State-owned power plants and two combined heat and power plants (CHPs). As a result the Southern Energy Company was established the biggest power generation company of installed capacity at around $5 \mathrm{GW}$ (a 14\% market share). The next consolidation took place in 2004 and involved merging of three power plants: Be1chatów SA Opole SA and Turów SA. As a result BOT Mining and Energy Company was established. The total installed capacity of BOT was to $7.9 \mathrm{GW}$ (market share of $22.5 \%$ ). The next consolidation of the Polish power sector ${ }^{1}$ that was carried out in 2006-2008 as a consequence of the Government's Programme for the Power Sector (2006) led to the creation of four State-owned energy companies. As expected consolidation of the power sector has led to a significant increase in the potential for market power in the power sector, and this is confirmed by a dramatic increase in the Concentration Ratios and the HHI (see (Kaminski, 2012)). In terms of ownership, they could be briefly described as both being state owned, and receiving an uneven part of generation assets. One of those consolidated companies, PGE SA, was given a substantial share of the low cost generation sector based on brown coal combustion. On top of that, PGE SA came to own approx. $40 \%$ of total capacity as a result of the introduction of the Programme. That clearly could not be interpreted as a step towards increasing competition in the electricity market. The transfer of cheap brown coal-based power generation assets to a company with such a high market share gives this company a competitive advantage.

The consolidation of the Polish power sector coincided with the process of termination of long-term contracts. Their share in the electricity trade was very high at that time (see Fig. 1), and this market reform was aimed at increasing the share of competitively traded electricity. Without freeing electricity from LTAs, there was no space for competitive trade. The withdrawal of LTAs and the mechanisms for compensation for stranded costs were initially perceived as successful.

\footnotetext{
1 As the Polish power sector, which is the subject of the case discussed in this paper, has already been described in the international literature, we deliberately omit further
} 
Fig. 1. The Share of LTAs in Total Wholesale Electricity Trade with Respect to Aggregates of Power Producers [\%]

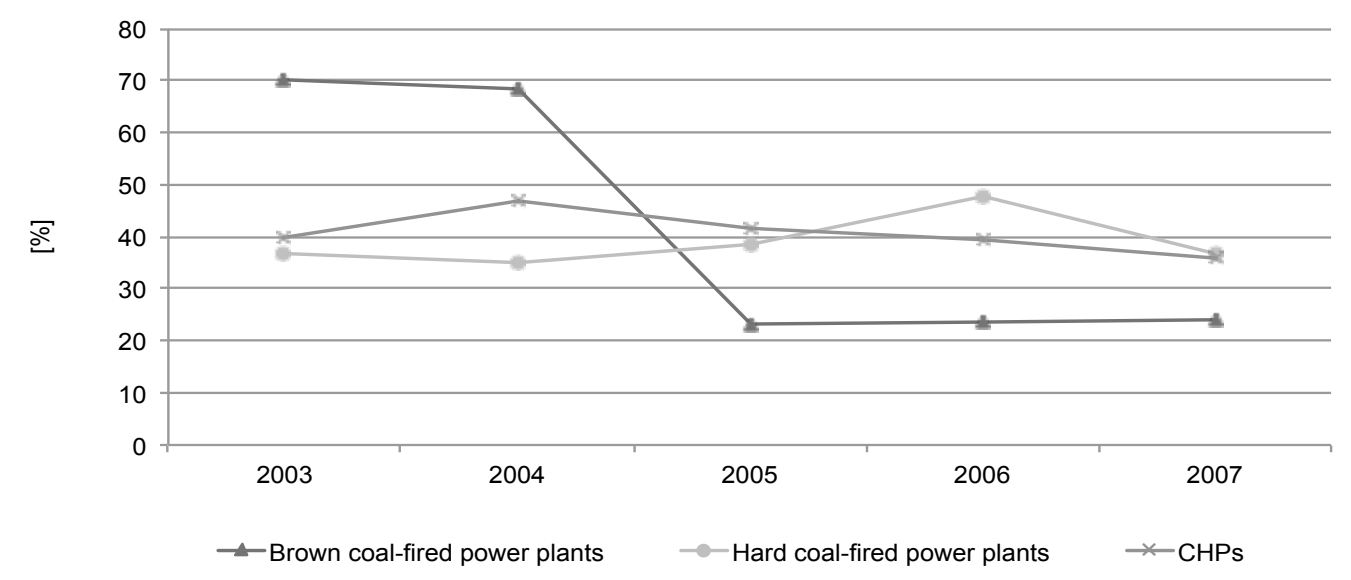

Source: own calculations based on Energy Statistics

Unfortunately, the introduction of those two crosscurrent reforms (consolidation and termination of LTAs) has quickly led to the malfunctioning of the power market. What happened was that power generation companies operating within vertically integrated energy groups started trading most of their electricity with electricity trading companies that were in the same capital groups. Although that should not be a problem per se, the real problem was that the prices in those contracts were significantly different from the prices in a competitive market (ERO, 2009) (ERO, 2010). This adverse effect of the termination of the LTAs has prompted the search for a policy tool that would help to correct this clearly identified market failure. It was even more urgent as a sharp increase in costs that would be incurred by industrial customers was expected due to the erroneous assumptions in the electricity price forecasts used in the development of the LTA termination programme.

When the reforms described above were introduced it was decided to remove the obligation to gain approval for the retail electricity tariff from the President of the Energy Regulatory Office (PERO). This decision was however rescinded because of the serious doubts regarding competition concerns, lack of liquidity and transparency of the electricity market. . The result was that electricity prices have increased dramatically, but only for non-retail consumers and energy-intensive industries were particularly affected. One of consequences of high electricity prices was the closure of an aluminium plant and protests by workers at other factories (see: Konin Aluminium Plant). The power exchange, which belongs to the commodity exchanges, is regulated in Poland in a separate legislation regime. In Poland, despite the existence of several wholesale energy trading platforms, the only one that was used by market participants was POLPX (Polish Power Exchange, in Polish: Towarowa Giełda Energii SA) in Warsaw. Initially it was a power exchange founded by market participants. Later, as a result of acquisition, it became an exchange owned 
by the Warsaw Stock Exchange. Its activities are currently as follows (POLPX):

1. management of the commodity exchange, supporting the trading of electrical power, liquid and gas fuels, production limits, more particularly electrical power production, pollution emission limits, property rights (electrical power values, liquid or gas fuels, production or emission limits);

2. clearing of exchange and OTC transactions;

3. management of a register for certificates of origin (renewable energy sources);

4. management of a register for certificates of origin (co-generation).

An insignificant share of trading in the power exchange was not accidental, as it was not an attractive marketplace for generators and wholesale traders, neither before the consolidation, nor after. As previously indicated, the consolidated energy companies very quickly came to the conclusion that trade within groups is the easiest way to increase profits. Higher electricity prices in in-group trading led directly to higher prices in the tariffs for final consumers, hence leading to extraordinary profits. It is therefore a classic example of market failure and negative externalities caused by the lack of implementation of the relevant regulatory solutions following the termination of LTAs and the consolidation of the energy sector. The problem was serious, which could be confirmed by the fact that in 2009 and 2010 the share of in-group trade was around $70-80 \%$ (Fig. 2), both in the case of hard and brown coal-based power producers.

Fig. 2. The Share of Electricity Trade within the Same Energy Group [\%]

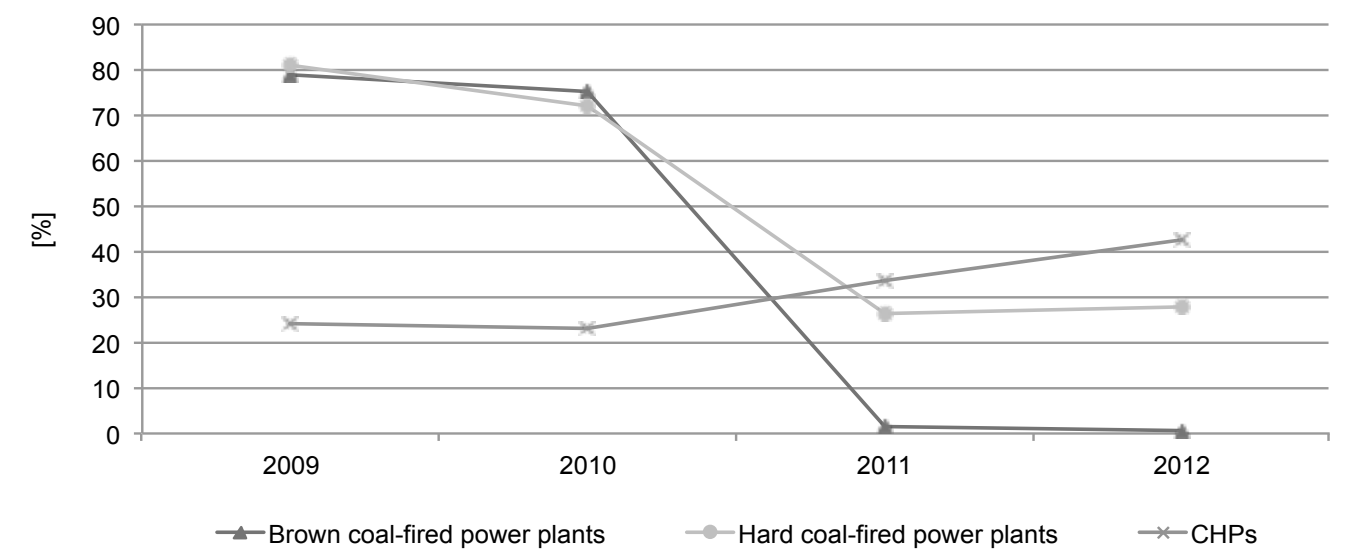

Source: own calculations based on Energy Statistics 
The only exception was PGE, which, due to its large excess production capacity, had to sell energy outside the group. In 2009, under bilateral agreements, generators sold over $90 \%$ of electricity to trading companies. Other markets were the balancing market (run by the TSO - Polish Power Grid Company) and, to a very small extent, the power exchange (Fig. 3).

Fig. 3. Destinations of Electricity Sold by the Power Generation Sector in 2009 [\%]

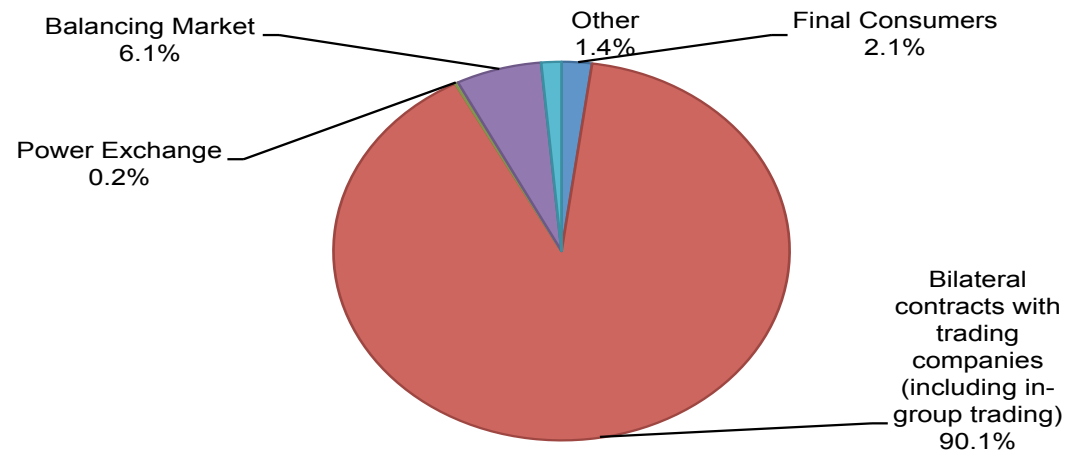

Source: (ERO, 2013)

As previously mentioned, the way electricity was traded directly translated to the level of the wholesale price of electricity. In the case of electricity produced by hard coal generators the average price of electricity increased from approximately 42.4 EUR/MWh in 2007 to $54.9 \mathrm{EUR} / \mathrm{MWh}$ in 2009 (i.e. by 30\%), and then declined slightly to 52.2 EUR/MWh in 2010. Similarly, the prices of electricity generated in brown coal-based power plants (operated by PGE SA and ZE PAK SA) increased from around 39.2 EUR/MWh in 2007 to 49.7 EUR/MWh in 2009 (i.e. 27\%) (Fig. 4). In both cases, the prices in the wholesale market increased by about $30 \%$ within two years, which was a phenomenon that had not been observed in the Polish energy sector.

Fig. 4. Annual Average Price of Electricity [€2012/MWh]

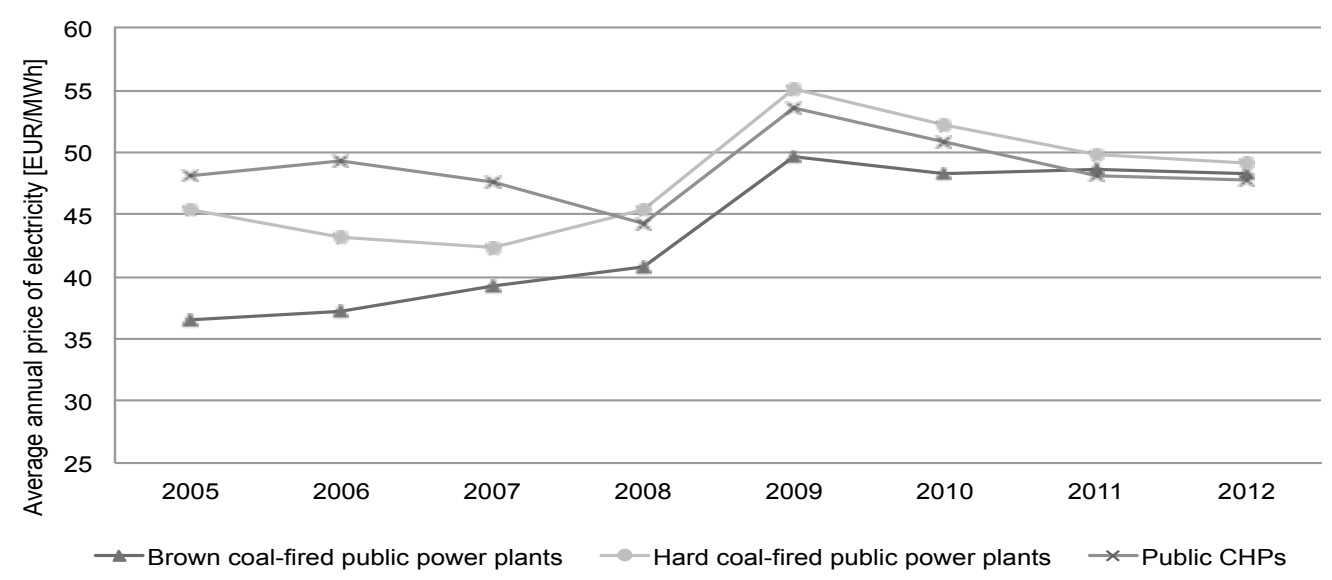

Source: own calculations based on Energy Statistics 
While searching for the reasons of such a significant increase in electricity prices, a natural step seems to be an analysis of generation costs. Consequently, during the period 2007-2009 analysed, the Long Run Marginal Costs (LRMC) of power generation in hard coal-fired power plants did indeed increase from 35.1 EUR/MWh in 2007 to 48.8 EUR/MWh (by 39\%) (Fig.5). This increase could easily be explained by soaring fuel costs resulting from an immense increase in hard coal prices in the world coal market. In consequence the fuel costs increased from 21.0 EUR/MWh to 32.7 EUR/MWh (by 56\%) between 2007 and 2009 (Fig. 4) which was a direct result of the change in fuel prices seen in Fig. 7.

Fig. 5. Average Annual LRMC [€2012/MWh]

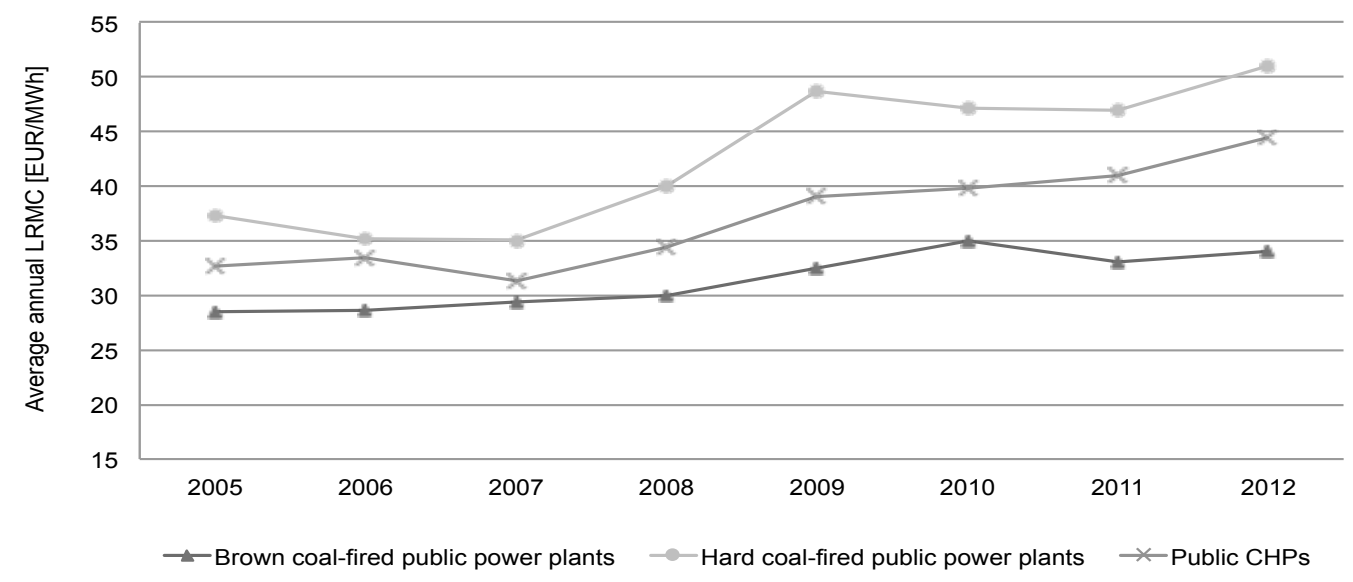

Source: own calculations based on Energy Statistics

While the increase in electricity prices of hard coal-fired power producers could be partially explained by exposure to very high hard coal prices, it is very difficult to apply the same reasoning to brown coal-fired generators. Owing to the fact that brown coal is exploited exclusively for power plants located close to open cast mines, they are independent from world coal market price fluctuations and they should be able to offer far lower and more stable prices (Grudziński, 2010). However, the price of power produced from brown-coal increased from 39.2 EUR/MWh in 2007 to 49.7 EUR/MWh in 2009 (Fig. 2), which is by approx. 27\%, a similar figure to that noted for power produced from hard coal. A similar analysis of the LRMC discloses an increase from 29.5 EUR/MWh in 2007 to 32.6 EUR/MWh (Fig. 5), which is only by $11 \%$. Furthermore, the fuel costs increased only by 15\% (from 16.8 EUR/MWh in 2007 to 19.3 EUR/MWh in 2009) (Fig. 6), which is also confirmed by the almost negligible increase in brown coal prices seen in Fig. 7.

Thus, brown coal-fired power producers took advantage of their position and increased the prices of electricity above the levels of normal profits, and since the wholesale electricity market was already deregulated it was almost impossible to take action to quickly improve the situation. 
Although such a situation required a solution at the national level, the government was not willing to introduce an instrument that would increase the transparency of electricity trade and lead to price reductions, and it was the President of the Energy Regulatory Office who replied to the requests of the energy intensive sector on this issue. The problem he faced was the lack of appropriate legal measures to introduce necessary systemic changes or to moderate the market behaviour of market players, so the only way was to introduce the changes needed into the Energy law.

Fig. 6. Fuel Costs [€2012/MWh]

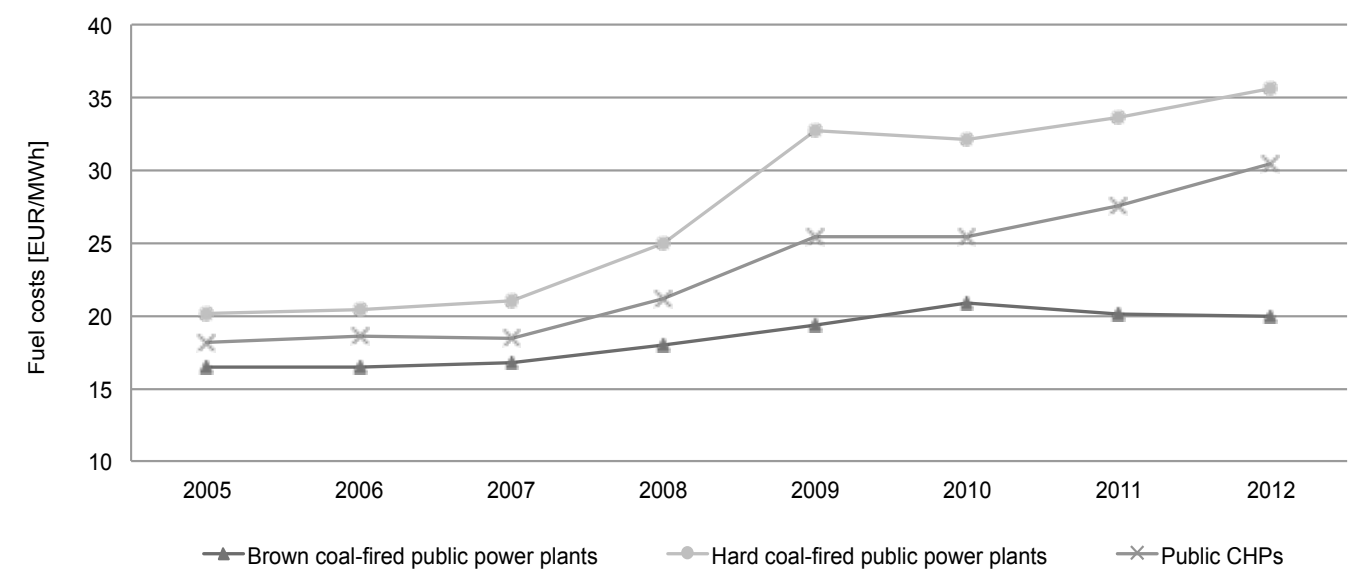

Source: own calculations based on Energy Statistics

Fig. 7. Fuel Prices in Supplies to the Power Sector [€2012/GJ]

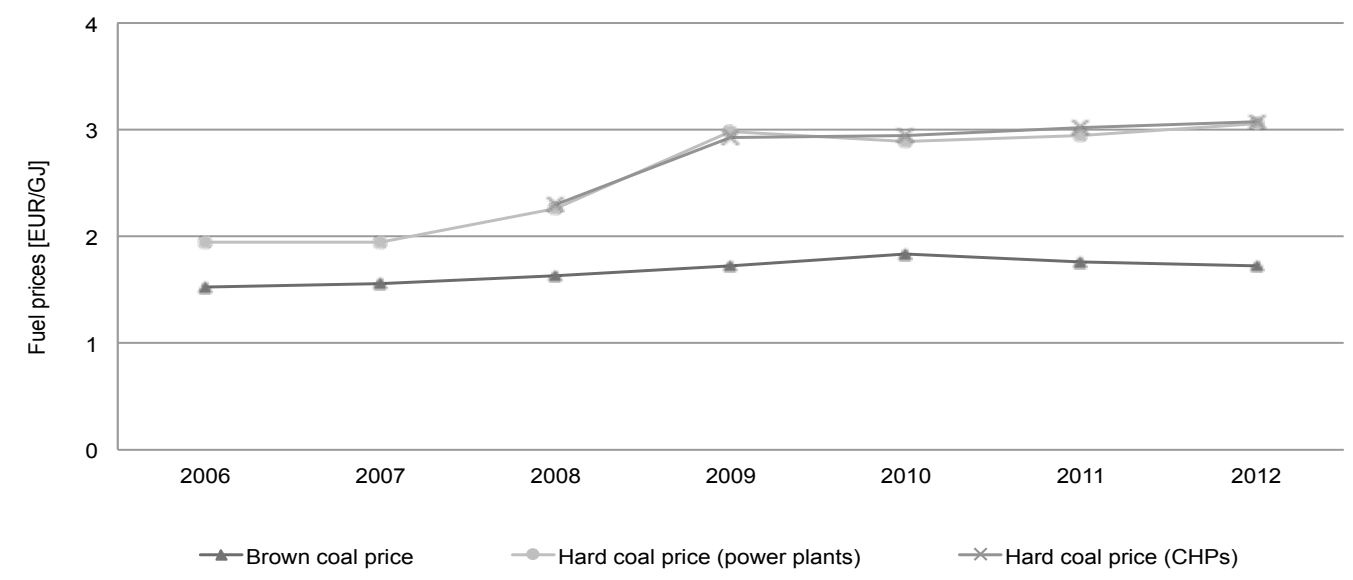

Source: own calculations based on Energy Statistics

The remainder of the paper is structured as follows. Section 2 discusses the methods that were applied to correct market failures in the Polish power sector outlined in section 1. Relevant policy tools that could be considered in the process of improving competition in the power sector were compared and analysed, and the most appropriate one is chosen. 
The regulatory and legislative aspects of PX duty to trade are analysed as well. Section 3 discusses the results - the consequences and outcomes of the introduction of the remedy into Polish Energy Law. The conclusions and key policy findings are summarised in section 4 .

\section{Methods and Data}

\subsection{Competition Law Remedies in the Wholesale Electricity Markets and Sector Specific Regulations}

As regards the methods that were applied to solve the problem outlined in section 1 we decided to use the Law and Economics approach and consider the assumptions involved in and economic effects of adopting specific legal measures. In other words, we analyse the outcomes of the introduction of legal rules introducing PX duty to trade (descriptive Law and Economics) with a view to providing a practical guide to policymakers, who face the problem of liberalisation of the wholesale energy market (normative Law and Economics) (Posner, 1981), (Stelmach and Brozek, 2006).

There are several instruments for enforcing competition law that theoretically could be applied when the specific objectives of increasing the transparency and liquidity of energy trade in the wholesale market are at stake. Application of those instruments is, however, strictly contingent upon specific market assumptions.

Market structures with a single dominant company or excessive concentration and lock-in trading inside vertically integrated energy companies are the circumstances that should predispose to a decision to implement such tools.

This section is dedicated to an analysis of competition law and regulatory instruments that encourage greater transparency and liquidity of energy trade and energy markets and that are possible to apply under national and EU law. For the reason of proper classification of those instruments, one has to begin with a review of the remedies applied in order to enforce competition law, which in general may be divided into two groups: behavioural and structural (Table 1).

Table 1. Types of Remedies in Competition Law and their Examples

\begin{tabular}{ll}
\hline \multicolumn{1}{c}{ BEHAVIOURAL REMEDIES } & \multicolumn{1}{c}{ STRUCTURAL REMEDIES } \\
\hline $\begin{array}{l}\text { Granting access to an infrastructure } \\
\text { Change or withdrawal of contract }\end{array}$ & $\begin{array}{l}\text { Divestiture of part or total of shares } \\
\text { Divestiture of the organised part of the } \\
\text { conditions }\end{array}$ \\
$\begin{array}{l}\text { undertaking or assets } \\
\text { Order to terminate the contract }\end{array}$ & Divestiture of subsidiary \\
Order to exchange the information & Order for division of company \\
\hline
\end{tabular}

Source: own analysis 
When mentioning the procedure of imposing remedies, we have in mind proceedings described and allowed for by EU competition law, which in general intends that an antitrust authority require that an undertaking actively takes certain measures proportional to the declared infringements (Hellstrom et al., 2009).

Undoubtedly both structural and behavioural instruments have certain advantages and certain disadvantages that make them particularly useful for specific issues (see Table 2). In the area of competition law behavioural remedies address the conduct of the undertakings by imposing duties and constraints on their behaviour. It is a commonly held view in the literature that a crucial strength of behavioural remedies is that they do not modify the structure of an undertaking and are therefore deemed able to deal with the competition concern in a more flexible, and less draconian, way (Tajana, 2006).

Table 2. Pros and Cons of Structural and Behavioural Remedies

\begin{tabular}{|c|c|c|}
\hline & ADVANTAGES & DISADVANTAGES \\
\hline \multirow{5}{*}{$\begin{array}{l}\text { Structural } \\
\text { remedies }\end{array}$} & & Pose unnecessary transaction costs \\
\hline & "Directly" effective & Costly if inefficient \\
\hline & More difficult to circumvent & Potential damage to innocent third \\
\hline & Relatively easy to administer & parties \\
\hline & Take effect quickly & $\begin{array}{l}\text { Reduce the incentive to compete } \\
\text { vigorously }\end{array}$ \\
\hline \multirow{3}{*}{$\begin{array}{l}\text { Behavioural } \\
\text { remedies }\end{array}$} & \multirow{3}{*}{$\begin{array}{l}\text { More respectful of proportionality } \\
\text { and of the rights of the parties } \\
\text { More flexible }\end{array}$} & $\begin{array}{l}\text { Do not properly address the excessive } \\
\text { concentration of market power }\end{array}$ \\
\hline & & Costly and burdensome to monitor \\
\hline & & and implement \\
\hline
\end{tabular}

Source: Tajana (2006).

In practice, behavioural remedies quite often (esp. in the case of commitment decisions) bring far reaching consequences for a company, especially when the ambition of the antitrust authority is not simply to execute competition law, but also to regulate the market. It is, however, worth mentioning that a disadvantage of taking only behavioural remedies is that firms may still have incentives to avoid compliance. As a result complementary instruments shall be also considered for potential implementation.

Both behavioural and structural instruments are used by the competition authorities in cases of infringements of Articles 101 and 102 of the Treaty on the functioning of the European Union (hereinafter: TfEU) and in cases of mergers and acquisitions. However in certain circumstances (described in the following section) they might be and are applied in cases of sector-specific regulation, which is a quite understandable situation considering the fact that the selection of measures designed to create a common energy market in the EU was 
based on a presumption of the necessity for a quick application of competition in the energy market, as well as by the means of adopting directives that contain competition law remedies (e.g. Third Party Access, Unbundling).

When dealing with remedies that could theoretically be applied in the regulation of the electricity wholesale market, one of the sources of inspiration might be the antitrust proceedings conducted by the EU Commission even before adopting the regulations and directives of the third liberalisation package and which accompanied the sector inquiry. In those cases the Commission imposed remedies that not only restore competition but are also intended to develop and deepen it. Taking this into account, the remedies imposed were de facto quasi-regulatory measures, an approach which is often criticized in the literature (for instance in (Hancher and de Vlam, 2004)). Behavioural remedies were the subject of a number of the Commission's commitment decisions, which were designed to:

1. increase the liquidity of the markets by limiting the concluding of long term energy supply contracts, since this category of contract leads to the exclusion of competitors (Distrigas, EdF, Electrabel);

2. granting access to essential facilities for competitors, including the transmission and distribution networks and gas storage installations owned by dominant undertakings (E.ON, RWE, GdF Suez)

3. deepening market integration by limiting the reservation of interconnector capacity by dominant undertakings (ENI, SvK) (Kloc-Evison and Koska, 2010).

The circumstances analysed here will refer to cases described in the first of the groups listed above. In our opinion a good example of a remedy that increases the liquidity of the markets by limiting the effects of long-term contracts is the decision adopted by the Commission in the Distrigas case (Bellantuono, 2009), (Spanjer, 2009) (COMP/B-1/37.966-Distrigas). This case concerned long term gas supply contracts in Belgium. In its preliminary assessment, the Commission expressed (on the basis of then art. 82 of the Treaty, now art. 102 TfEU) concerns that long term gas supply contracts with large industrial customers concluded by Distrigas may render it impossible for those customers to switch to another supplier and moreover limit the possibilities for other gas suppliers to conclude contracts, excluding them from the market. The commitments proposed by Distrigas and approved by the Commission are presented in Table 3.

The Distrigas case, where the Commission tried to improve the situation of industrial customers who were bound by long term contracts, is an example of applying a very interesting instrument i.e. a duty to release gas (or gas release programme). 
Table 3. Commitments Proposed by Distrigas and Approved by the Commission DISTRIGAS COMMITMENT TYPE OF REMEDY

On average a minimum of $70 \%$ of the gas volumes supplied by Distrigas and connected undertakings to industrial users and electricity producers in Belgium will return to the market each year. If Distrigas' total sales decrease from their 2007 level, then Distrigas will be able to tie a certain fixed volume of gas sales, which represents less than 20 $\%$ of the total market concerned

Contracts with industrial users and electricity producers cannot be longer than five years, however contracts relating to new power plants with a capacity exceeding $10 \mathrm{MW}$ are not subject to the commitments

Distrigas commits itself not to conclude any gas supply agreements with resellers with a duration of over two years

Distrigas confirms that it will not introduce use restrictions into its supply contracts.

Duty to release certain gas volumes

Restriction of length of contracts (with de minimis exception)

Duty not to conclude a contract with reseller for a certain time

General duty not to put restrictions in supply contracts

Source: own based on Distrigas commitment decision

This remedy consists of a commitment by the dominant seller to release onto the market gas from long term contracts and offer it to other market players. Such a measure, though interfering with the contract obligations, brings potential advantages through increasing the liquidity of the market and limiting barriers to entry. The Distrigas case concerns the gas market but this type of action also applies (and was also applied) to the electricity market, though in slightly different form as the techno-economic character of the electricity market is different.

A measure that is specifically designed to promote competition in the electricity market and has been relatively often applied to it is the Virtual Power Plant (VPP) auction, described as: sales of electricity capacity which, rather than "physical" divestitures, are "virtual" divestitures by one or more dominant firms in a market. Instead of selling the physical power plant, the firm retains management and control of the plant, but offers contracts that are intended to replicate the output of the plant. Typically, these contracts are sold as divisible goods of varying durations, offered in periodic open and transparent auctions (Ausubel and Cramton, 2010). This type of auction was applied for example in the EDF case as a behavioural measure to be used while assessing EDF's intention of purchase $1 / 3$ of the shares of the German utility EnBW, and to do that EDF agreed to make $6000 \mathrm{MW}$ of virtual capacity available in France in order to increase competition in the market. EDF was at the time selling to 
around $90 \%$ of the so-called free consumers in the French market (Schultz, 2005).

What makes VPP close to our case are the essential characteristics taken into account by the regulators when adopting decisions on VPP, which are:

- facilitating entry into the electricity market by assuring the availability of electricity supplies on the high-power grid to new entrants;

- promoting the development of and adding liquidity to the wholesale electricity market; and

- reducing market power in the spot electricity market (Ausubel and Cramton, 2010).

Similar essential characteristics were considered before the introduction of the PX duty to trade that we analyse in this article.

Examples of the solutions mentioned above (namely gas release and the VPP auctions) are mainly applied by the competition authorities as remedies in the course of proceedings against dominant companies and during assessment of mergers and acquisitions. The use of such remedies in the framework of sector specific regulation is authorized by both market directives (2009/72, 2009/73), which, among other powers of NRAs, lay down the power to carry out investigations into the functioning of the electricity markets, and to decide upon and impose any necessary and proportionate measures to promote effective competition and ensure the proper functioning of the market. This regulation provides the basis for establishing the powers of NRAs in national law, which might raise some concerns in terms of their relations with competition law. The EU law here refers to effective competition and proper functioning of the market, which are naturally associated with a competition law regime. Literature and specialists claim in general that the implementation of those regulations may assume the form of specific national provisions on virtual power plants or gas release programmes that apply to concentrated markets with historically incumbent undertakings that preserve their rights resulting from long term import contracts (Cabau, 2010). In the case of VPP this is indirectly confirmed by the recital 37 of preamble to directive 2009/72, which stipulates that: The establishment of virtual power plants - electricity release programmes whereby electricity undertakings are obliged to sell or to make available a certain volume of electricity or to grant access to part of their generation capacity to interested suppliers for a certain period of time - is one of the possible measures that can be used to promote effective competition and ensure the proper functioning of the market. It should be underlined that in this provision EU law equates VPP to electricity release programmes which are based on imposing on the incumbent dominant company an electricity sale obligation in favour of competitors to render it possible for them to enter the market (Chatonet al., 2010). Implementing the possibilities offered by art. 37(4)(b) of Directive 2009/72/EC and art. 41(4)(b) of Directive 2009/73/EC are not only limited to VPP and gas release 
programmes but may also be related to specific programmes concerning particular subsectors, like e.g. storage or transmission (Commission 2010). In our opinion, those provisions, however, do not restrict national legislators to regulating only such programmes as are mentioned above. One should consider that Member States (taking into account specific national market conditions) may on the grounds of those provisions also regulate for other instruments that are designed to promote effective competition and ensure the proper functioning of the market, while taking into account the proportionality and adequacy rules. Thus, the 3rd liberalization package offers the basis for applying remedies in sector specific regulation that are borrowed from competition law.

In theory the possible effects of consolidation on the behaviour of a company in the retail and wholesale markets rely on several parameters. A recent study by (Bunn et al., 2015) lists among the others the following: risk aversion of retail companies, as well as the relative concentration in the retail and wholesale market [see (Bunn et al., 2015) for further discussion].

\subsection{Introduction of the PX Duty to Trade into the Energy Law}

In section 1 we argued, that in 2008 - 2010 there were grounds for state intervention concerning the malfunctioning of the electricity market. Although the process of adjusting the market should have been commenced either by Parliament or the Government, it was the energy regulator who was most interested and active in intensifying competition in the electricity sector. The 2010 amendment to the Energy law, which included provisions concerning the PX duty to trade, was a difficult process, mostly due to the reluctant position of government.

One of basic arguments against the introduction of PX duty to trade was a concern about the monopolizing of the wholesale trade exclusively by one power exchange. Those arguments were raised both by politicians and smaller trading platforms that were afraid of the largest entity, POLPX, dominating the trade. It was not understandable on what grounds this reasoning was based, as the functioning of a single PX is a natural state for several power markets due to:

- the specificity of exchange fares, that favour larger markets;

- a higher level of liquidity, which is the value of an exchange to a participant (Frontier, 2005).

In consequence of this, in most European countries there exists only one power exchange. Concerns were also raised with regard to the restriction of investment in the generation sector, which argued that only OTC contracts may be credible collateral for bank credits (see: A letter of EFET to the Minister of Economy (8.12.2017)).

It was even more difficult to get this accepted since it was not stipulated in European law, which states no duties on Member States in that respect 
regarding implementation (Muras and Elzanowski 2010). Polish energy law closely follows the EU Energy directives and arguments for means of implementation could make a legislative proposal easier to accept by policymakers. A certain analogy may be detected in the measures that can be used to promote effective competition and ensure the proper functioning of the market, which may be adopted by the Member States, according to recital 37 of the preamble to Directive 2009/72/EC. This provision refers rather (as we argued above) to VPP and the gas release programmes as individual measures, while the PX duty to trade concerns the whole energy market, and may be described as an example of a measure supporting liquidity which reinforces the position of the power exchange (Meeus, 2010). Thus, the solution adopted was not based on the explicit norms of the EU directives, rather it was a specific instrument in support of the market liberalisation process, introduced by national law as a reaction to serious competition concerns regarding the Polish energy market (Swora, 2013).

Regarding the introduction of PX duty to trade, in 2009 - 2010, one could also consider using the tools provided in competition law. The problem was that the Polish competition authority (President of the Office of Competition and Consumer Protection, hereinafter: POCCP), did not have a proper cause for action (like a merger case or other case with a view to issuing a commitment decision) and what is even more significant - specific knowledge on how the electricity market functions. On the other hand, having such specific knowledge, the PERO was not equipped with powers that could have effectively improved the situation on the market. As a consequence, a remedy such as VPP auctions could not have been applied. In such a case, the only thing to do was to refer the matter to government to try to persuade it of the necessity to initialise the legislative procedure (Fig. 8).

In 2009-2010 there were good grounds for proposing changes that could have improved the malfunctioning electricity market, as prices were high and industrial energy users argued that such a situation might cause bankruptcies (esp. in energy intensive industries). A good occasion to introduce such a change was during the process of amending the Energy Law, which commenced in 2009. Eventually, the PX duty to trade was regulated in the Act of 8 January 2010 amending the Energy Law of 2007.

The PX duty to trade stipulated in art. 49a of the Energy Law is of a general character. It applies to every participant operating in the generation sector, which is obliged to sell at least $15 \%$ of the electricity generated in a particular year through the power exchange. However, a specific obligation is imposed on generators covered by the programme for the terminating of long term contracts (hereinafter: ex-LTA generators) who have to offer the whole volume of electricity produced in a given year in power exchanges. 
Fig. 8. Division of Powers and Competition in Energy Markets

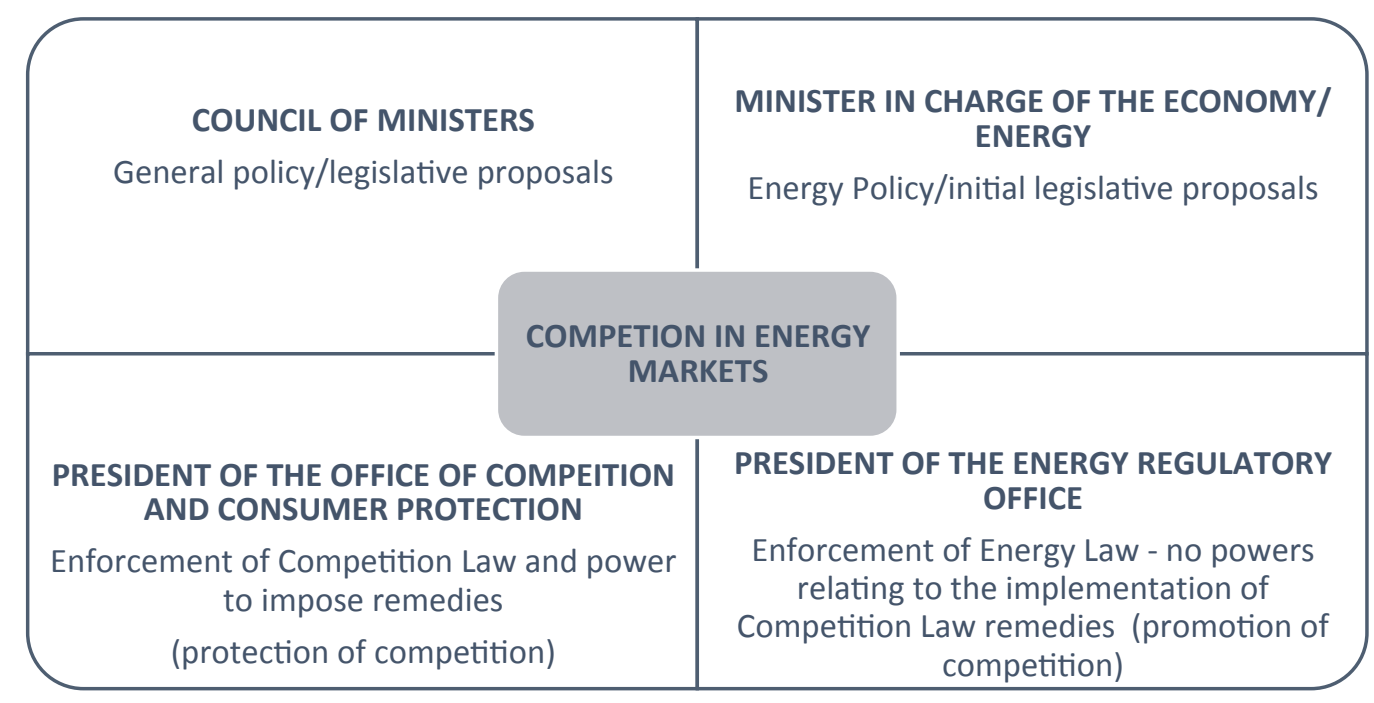

Source: own analysis

This aggravated rigour was the consequence of the necessity of obtaining the correct state aid clearance that was granted in favour of those generators who voluntarily terminated their long term contracts. It may be questioned however whether the obligation was correctly targeted, taking into account the abovementioned specificity of the Polish power generation market which was dominated by one energy holding (PGE SA). The obligation was imposed on all market participants, regardless of their market share. However, the instrument was imposed mainly to the incumbent generators (units) that are to benefit from aid in respect of stranded cost. They are obliged to sell $100 \%$ of electricity via PolPX for as long as they received the aid. All the other generators (each unit treated independently) are obliged to sell only 15\% in the spot market. Consequently, these producers are able to hedge risk in the forward markets, such as the Commodity Forward Instruments Market with physical delivery. In these cases price formation can take place either in the power exchange or in bilateral transactions, as forward contracting outside the PolPX is not forbidden.

An example of a more targeted measure is the provision of art. 111 of the Hungarian Electricity Act 2007, according to which the obligation to sell in the power exchange market may be imposed on market players having significant market power in the wholesale market. The energy regulator conducts an assessment of significant market power (equivalent to a dominant position) in the relevant markets. Hungarian electricity law also includes another interesting instrument (to the best of our knowledge never applied by the energy regulator), which applies to all generators above $20 \mathrm{MW}$ and traders with available free capacity and obliges them to sell their free capacities scheduled for the next year under an open and 
transparent procedure. This obligation may be carried out by selling capacities through power exchange markets.

Comparing Hungarian and Polish provisions on PX duty to trade (exchange trade obligation), one may isolate two models of PX duty to trade (the exchange trade obligation, this measure):

1. a general obligation - imposed on all entities in the generation sector;

2. targeted obligations - imposed on certain parts of the generation sector (e.g. ex-LTA generators) or a dominant firm.

Regarding the implementation of both models, where entities are defined in general terms in statutes (like is the case with the general (exchange trade obligation) PX duty to trade or in targeted obligations which concern ex-LTA generators), there is no need for an additional decision of the NRA, which is only supervising the execution of the duty and may impose a sanction.

In the case of targeted obligations imposed on a dominant company it is first of all crucial to define the relevant market that the regulator feels should be the subject of an individual decision. This means that in a typical situation the procedure is of considerable length, although there is the unquestionable advantage of the more tailored features of a targeted obligation measure.

Referring back to the scope of the obligation, it should be assumed that the choice of covering a wide spectrum of market participants and not only the dominant undertaking was due to the economies foreseen in implementing the law and the conservative approach of (at least some) policymakers.

The Polish Energy Law does not envisage individual powers of the regulator to decide upon and impose any necessary and proportionate measures to promote effective competition and ensure the proper functioning of the market (Article 37(4)b of Directive 2009/72/EC). One of the reasons for this omission is the rather strict approach to the division of powers between the systems of energy regulation and protection of competition.

The Polish antitrust authority is traditionally very reluctant to share its competences with the energy market regulator. This approach was very clearly presented during the discussions on the amendment to the Energy Law 2007 and the new energy and gas laws (drafts from 2012) that were supposed to implement the provisions of Directives 2009/72/EC and 2009/73/EC.

Finally, the amendment did not contain regulations on powers, which would enable the NRA to impose individual measures aimed at ensuring the proper functioning of the gas market (Swora, 2013). In consequence, the Polish energy market regulator - unlike the telecommunications market regulator - has no powers to carry out assessments of significant 
market power and impose regulatory duties on companies holding such power (Wach, 2011).

Table 4. A Comparison of Pro-liquidity Remedies

\begin{tabular}{|c|c|c|c|c|}
\hline REMEDY & $\begin{array}{l}\text { EXPECTED } \\
\text { EFFECT }\end{array}$ & SUBJECT & BASIS & MECHANISM \\
\hline $\begin{array}{l}\text { GAS RELEASE } \\
\text { PROGRAMM } \\
\text { E }\end{array}$ & $\begin{array}{l}\text { More } \\
\text { liquidity, } \\
\text { lower } \\
\text { barriers to } \\
\text { entry }\end{array}$ & $\begin{array}{l}\text { Energy } \\
\text { company } \\
\text { holding } \\
\text { dominant } \\
\text { position }\end{array}$ & $\begin{array}{l}\text { Decision } \\
\text { of } \\
\text { Antitrust } \\
\text { Authority }\end{array}$ & $\begin{array}{l}\text { Contractual/auctions/auctio } \\
\text { ns on PXs }\end{array}$ \\
\hline VPP & $\begin{array}{l}\text { More } \\
\text { liquidity, } \\
\text { lower } \\
\text { barriers to } \\
\text { entry }\end{array}$ & $\begin{array}{l}\text { Energy } \\
\text { company } \\
\text { holding } \\
\text { dominant } \\
\text { position }\end{array}$ & $\begin{array}{l}\text { Decision } \\
\text { of } \\
\text { Antitrust } \\
\text { Authority }\end{array}$ & Auction \\
\hline $\begin{array}{l}\text { HUNGARIAN } \\
\text { PX DTT }\end{array}$ & $\begin{array}{l}\text { More } \\
\text { liquidity, } \\
\text { lower } \\
\text { barriers to } \\
\text { entry }\end{array}$ & $\begin{array}{l}\text { Energy } \\
\text { company } \\
\text { with } \\
\text { significant } \\
\text { market } \\
\text { power }\end{array}$ & $\begin{array}{l}\text { Decision } \\
\text { of NRA } \\
\text { (SMP) }\end{array}$ & Power exchange \\
\hline $\begin{array}{l}\text { POLISH PX } \\
\text { DTT }\end{array}$ & $\begin{array}{l}\text { More } \\
\text { liquidity, } \\
\text { more } \\
\text { transparenc } \\
\text { y, limitation } \\
\text { of insider } \\
\text { trading }\end{array}$ & $\begin{array}{l}\text { Every } \\
\text { generator/LT } \\
\text { A generators- } \\
\text { programme } \\
\text { beneficiaries }\end{array}$ & $\begin{array}{l}\text { Ex lege } \\
\text { (NRA } \\
\text { monitors } \\
\text { and } \\
\text { imposes } \\
\text { sanctions } \\
\text { ) }\end{array}$ & Power exchange \\
\hline
\end{tabular}

Source: own analysis

The PX duty to trade through the power exchange is not absolute as there are certain exceptions, either directly stated in the Energy Law (ex lege) or determined by the NRA through its decisions issued on the legal basis as stipulated in Energy Law (Table 5). Those exceptions are mostly justified on technical and economic grounds and are the consequence of the specific features of generating sources. Moreover, taking into account concerns about investment stability, the Polish legislator also excluded energy sold on the basis of contracts that are collaterals to obligations resulting from contracts concluded with financial institutions. An important condition is that the exception granted by the NRA's decision 
may only apply if it will not result in a serious disruption of competition on the energy or balancing markets. There were only few individual exceptions granted by PERO on these grounds.

Table 5. Exceptions from the Obligation in 2012

\begin{tabular}{lc}
\hline \multicolumn{1}{c}{ EXCEPTIONS EX LEGE } & SHARE \\
\hline $\begin{array}{l}\text { energy provided by the generator to the final customer via direct } \\
\text { line }\end{array}$ & $0 \%$ \\
$\begin{array}{l}\text { energy generated from RES (renewable energy sources) } \\
\text { energy generated in CHP with a defined average efficiency } \\
(>52,5 \%)\end{array}$ & $38 \%$ \\
energy used by the generator for its own purposes & $27 \%$ \\
$\begin{array}{l}\text { energy necessary for electricity system operators to perform their } \\
\text { statutory tasks } \\
\text { energy generated in a plant that has a total installed electrical } \\
\text { power < } 50 \text { MW }\end{array}$ & $17 \%$ \\
\hline \multicolumn{1}{c}{ EXCEPTIONS BY THE DECISION OF PERO } \\
\hline $\begin{array}{l}\text { energy sold for the purposes of execution of long term obligations } \\
\text { deriving from contracts concluded with financial institutions in } \\
\text { order to realize investments related to electricity generation; } \\
\text { energy generated for the purposes of TSO and used for the } \\
\text { purposes of correct functioning of the electricity system. }\end{array}$ & $0 \%$ \\
\hline
\end{tabular}

Source: own based on ERO (2013).

The generators submit reports regarding trade on the PX, based on art. $49 \mathrm{a}(9)$ of the Energy Law as PERO supervises the execution of the exchange obligation. A financial penalty may be imposed by PERO on a generator in case of failure to fulfil the obligation.

It may prima facie raise constitutional concerns that imposing a specific way of energy trading on energy companies can constitute a violation of their freedom to carry on economic activity.

In our opinion, competition in the electricity market is the value that overbalances these concerns in so far as the duties imposed proportionally address market imperfections and bring liquidity and transparency. As the economic analysis proves, the successful introduction of market reforms results in increasing competition, hence reduces dead weight loss, and improves the social surplus. As an example, an analysis that was carried out with the employment of the computable model based on the Cournot approach improved by the inclusion of Conjectural Variations (Kamiński, 2011) showed that market power in the Polish power generation sector has a significant impact on wholesale electricity prices and production volumes. The result confirmed that under the competitive scenario the average wholesale electricity price would be approximately $6.5 € / \mathrm{MWh}$ lower when compared to the reference scenario. The dead 
weight welfare loss was estimated at the level of 123.6 M€ annually (Kamiński, 2011).

\section{Results and Discussion}

The introduction of the PX duty to trade caused a huge drop in in-group electricity trade, to approx. 25\% in 2011 and 2012 in the case of hard coal-based power producers and plummeted to almost zero in the case of brown coal-fired power generators (Fig. 2).

Consequently the power exchange had already become a key power-trading platform in 2011. While in 2009 the sale of electricity through the power exchange was practically negligible regardless of whether it related to hard- or brown coal-based power production, in 2010 it amounted to $4.2 \%$ and it reached $58.7 \%$ in 2011.

Bilateral contracts accounted for less than $40 \%$ of all forms of wholesale trade, whereas in the year before this the share amounted to $89.8 \%$. The remaining sales were mostly carried out through the balancing market and power was only sold to foreign buyers to a limited extent (ERO 2012). In 2012, the number of commercial transactions carried out through the power exchange increased to $61.8 \%$ of the volume of electricity sold by generators (ERO 2013). The changes in the crucial years 2010-2011 are depicted in Fig. 9.

Fig. 9. Shares of Electricity Markets - Consequences of the Introduction of the PX Duty to Trade (2010-2011)
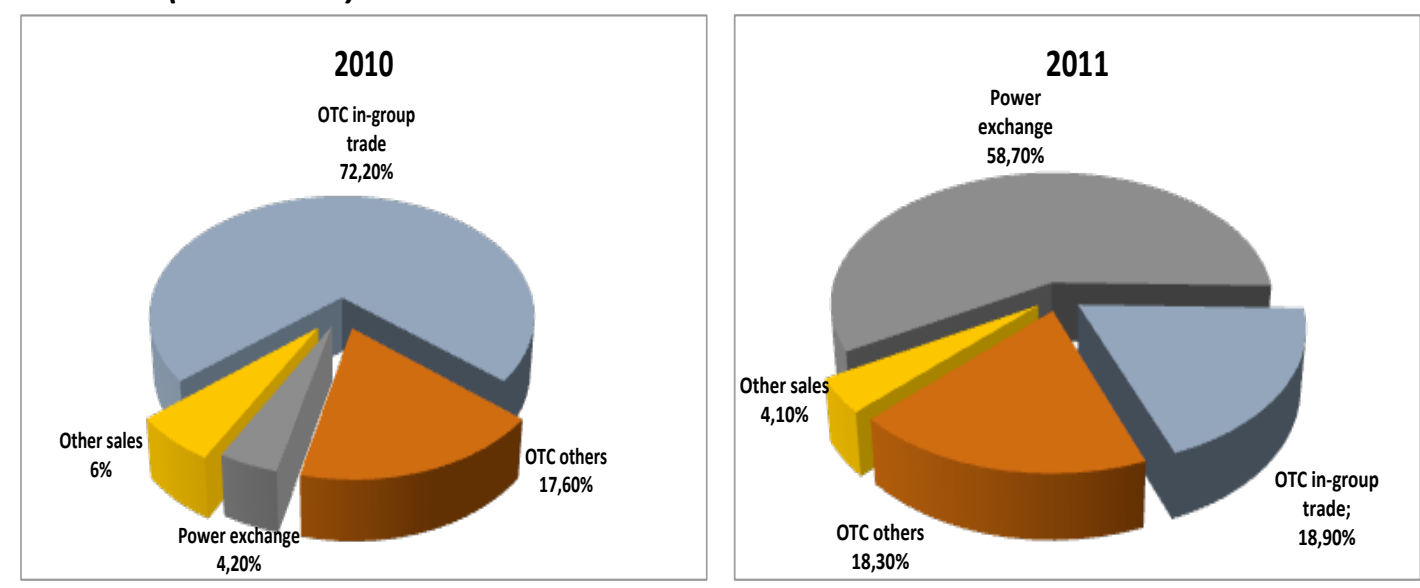

Source: ERO (2013).

A more detailed analysis shows that hard coal-fired power generators sold practically $60 \%$ of their electricity through the power exchange while the brown coal ones increased the share of PX trade to $73 \%$ in 2011, and to 82\% in 2012 (Fig. 10). 
Fig. 10. The Share of Electricity Trade Through the Power Exchange [\%]

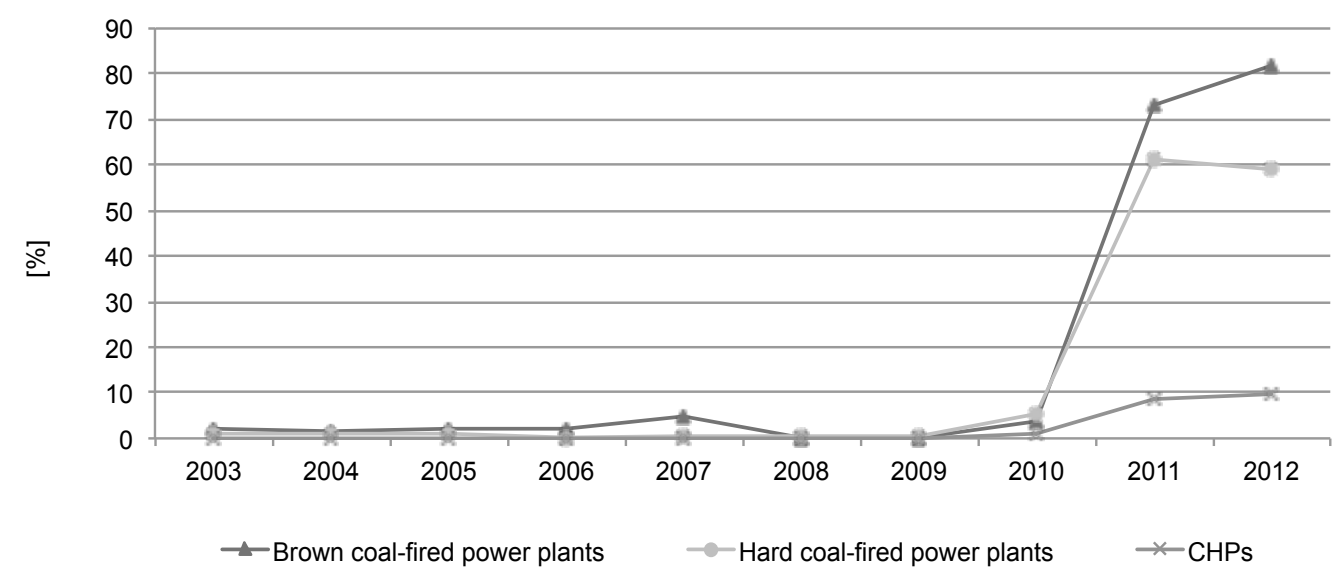

Source: own calculations based on Energy Statistics

As far as prices are concerned, there is a substantial price convergence observed after the introduction of the obligation. While in 2010 the difference between hard and brown coal-fired generation prices was approx. 3.87 EUR/MWh, in 2011 it was 1.11 EUR/MWh, and in 2012 it was only $0.72 \mathrm{EUR} / \mathrm{MWh}$ (Fig. 4). That observation is typical of a situation where there is a high share of trade via a power exchange, as there is only one clearing price regardless of technology or fuel. Therefore, there is no technological differentiation that theoretically could be taken into account in bilateral contracts. That outcome is of crucial importance because now the more expensive hard coal-based power plants are forced to increase their economic efficiency (cut costs) in order to be competitive in the electricity market. There is another fact supporting this observation, resulting from a comparison of hard coal-fired generation prices and costs. While the LRMC costs ${ }^{2}$ of those power plants increased by $8.4 \%$ in 2012 (in comparison with 2011), the price of electricity dropped only by $1.4 \%$. Moreover, the analysis of the Lerner Index based on LRMC shows that in the case of hard coal power plants, after the introduction of PX duty to trade, the value of the Lerner Index dropped from 0.1 in 2010, to 0.05 in 2011, and -0.04 in 2012. The negative value of the Lerner Index means those power plants generate losses on electricity production. Another consequence is that brown coal power generation takes advantage of lower costs hence their LRMC-based Lerner Index maintains a level of 0.3, which is very high (Fig. 11). This situation could change if CO2 permits become more expensive, as brown coal-fired power generation emits more $\mathrm{CO} 2$ per MWh, therefore they would be exposed to a higher cost burden resulting from the ETS.

\footnotetext{
2 Please note that in the calculations extra marginal plants are not taken into account and only those plants that were dispatched are included.
} 
Fig. 11. Lerner Index Based on LRMC

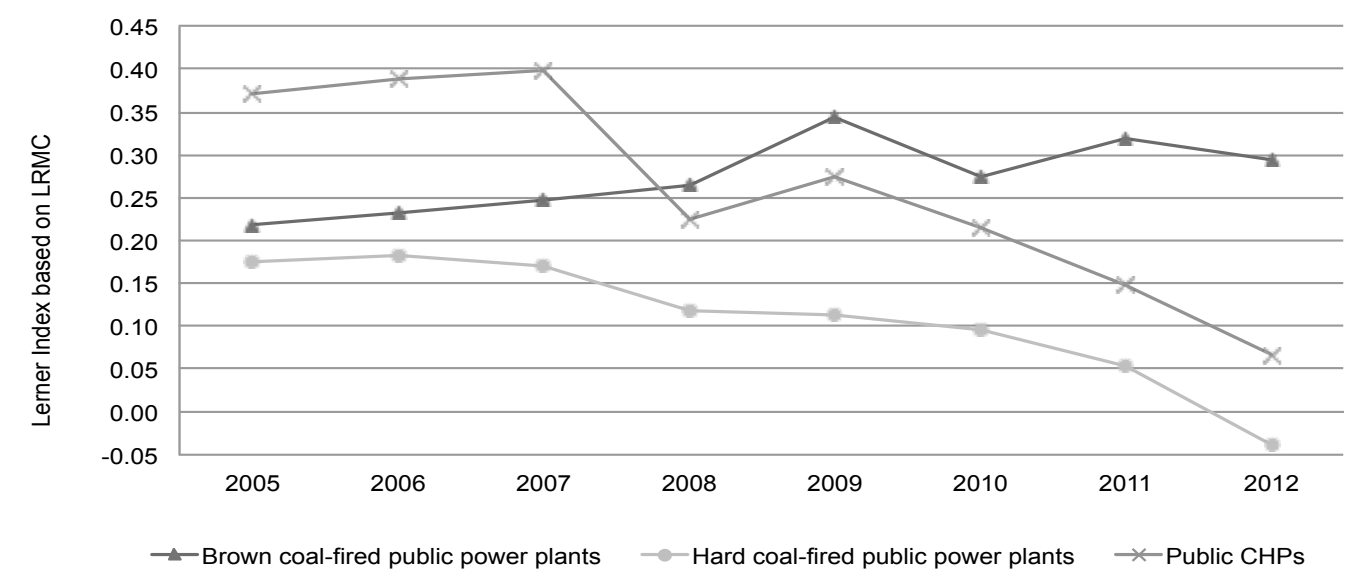

Source: own calculations based on Energy Statistics

An analysis of the SRMC-based Lerner Index further confirms the previous findings. The introduction of the PX duty to trade intensified the decline in its values in 2012 in the case of hard coal-based power generation (to approx. 0.22 ), with CHPs producing a similar outcome. It is worth noting that brown coal-fired power generators managed to keep the price-cost margin at the level of 0.54 , which is a huge value, in particular when compared to other technologies (Fig. 12).

Fig. 12. Lerner Index Based on SRMC

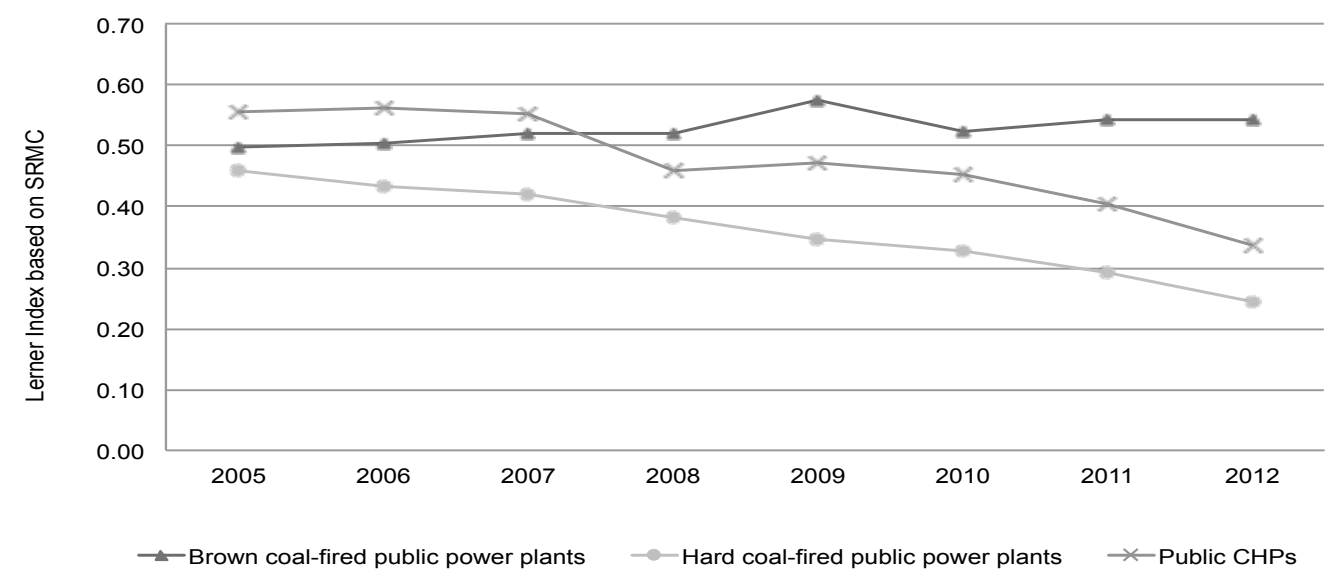

Source: own calculations based on Energy Statistics

These results all confirm that this way of trading electricity has been accepted by the participants in the wholesale market. This fact is also confirmed by the official position of the Association of Energy Trading (Towarzystwo Obrotu Energia - TOE), a voluntary, self-governing and apolitical non-profit organisation established in 2003. This association, although initially reluctant to support the PX duty to trade, assessed the 
introduction in 2012 in the following way: while TOE is somewhat concerned about the administrative obligation imposed on generators to sell electricity through a prescribed trading platform, the experience so far is positive, with greater liquidity in the market, more credible price indexes and the Electricity Commodity Exchange becoming increasingly user-friendly (TOE, 2012). Also the current President of the ERO concluded that: the obligation to electricity generators to sell generated electricity through the power exchange, which came into effect on 9 August 2010 under Article 49a of the Energy Law, brought about the expected effects (ERO, 2012). The effects that were achieved owing to the introduction of the PX duty to trade can be summarised as follows:

- ensuring equal access by market participants to electricity traded in Poland by ensuring equal conditions of participation in power exchange trading;

- $\quad$ ensuring transparency of electricity trading by guaranteeing equal access to information inter alia on electricity prices and conditions for participation in electricity trading;

- ensuring accurate prices of electricity by directing a large part of the wholesale electricity trading into an organized market which is the Commodity Exchange, while maintaining supervision by the Financial Supervision Commission. This supervision is supposed to eliminate the possibility of manipulation of electricity prices - especially in a market such as one in which there are companies with a strong market position;

- simplifying the energy trade process from the perspective of consumers, hence increasing their position and strength in the electricity market;

- $\quad$ ensuring the safety of the settlement of financial transactions by a licensed Warsaw Commodity Clearing House (ERO, 2012).

Even if we assume that PERO as the author of the idea of the PX duty to trade could not present a view other than positive, the economic facts and general approval of market players, leads us to a positive assessment of this specific regulatory measure.

\section{Conclusions}

PX duty to trade belongs to the family of regulatory measures that may be applied to improve liquidity and transparency in the wholesale electricity and/or gas markets. Implementation of PX duty to trade was an appropriate response to serious problems that were affecting the Polish electricity market in 2008 - 2009, namely the (i) lack of transparency of the power trade, (ii) negative effects of vertical integration, (iii) horizontal 
consolidation, (iv) termination of the LTAs, (v) deregulation of prices for industrial customers and (vi) lack of credible price indexes. Those issues, in addition to increasing coal prices, have caused the dynamic increase in energy prices. The mechanism that was sought was supposed to put such a difficult market situation in order. One of the solutions debated was to introduce administrative measures and strengthen price control, but finally it was decided to accept arrangements that were supposed to improve competition: the introduction of PX duty to trade. Adoption of this pro-market measure during the financial crises, when proposals to reregulate the market are more likely to be on the top of the politicians' wish list, was not an obvious choice; but it worked. The ultimate effect of the legislative changes was a greater liquidity and transparency in the market and a reliable price index. PX duty to trade, classified as an example of liquidity supporting measures, though initially being questioned and opposed by the market participants, was finally accepted, which may be confirmed by the volumes traded on the PX.

Energy covered by the PX duty to trade (at least $15 \%$ generated by all producers and $100 \%$ generated by producers who used to be bound by an LTA) translates into $74.8 \mathrm{TWh}$, which is approximately $51 \%$ of the gross electricity generated by those companies. According to 2012 data, generators sold 81.5 TWh (out of a total electricity production in Poland of 150 TWh) through the power exchange. Taking into account the exceptions it is quite clear that the energy generators internalised the obligation to sell energy through the power exchange which became not just an unwanted administrative burden but also an accepted market mechanism. As far as the economic results are concerned, improved competition in the electricity market forced hard coal-based power generators to reduce prices, which translated to a significant drop in the value of the Lerner Index. For those power generators the LRMC-based Lerner Index plummeted to -0.04, and the SRMC-based one to 0.22. Such low price-cost margins have never been observed in the Polish power market. Additionally there has been a substantial convergence of prices, and the differences between hard and brown coal-fired generation prices are only of the order of $0.7 \mathrm{EUR} / \mathrm{MWh}$.

On the other hand, it has to be pointed out that PX duty to trade did not change the competitive situation on the supply side of the market, as it did not bring in new entrants. It also did not diminish the market power of the dominant player, which results from cost differences between hard and brown coal-fired power generation. Individually applied VPP auctions would surely be more effective in this respect. However, it worked on the demand side, creating a more liquid and transparent wholesale market and new opportunities for traders. Regulation of the possibility to apply for an exemption when there is a need to guarantee a bank loan was protected against objections regarding the anti-investment character of that measure (such objections were presented e.g. by critics of the gas release programme in Distrigas). Last but not least, a competitive wholesale market has been created, enabling proper settlement of compensation of terminated LTAs. And although there are other 
upcoming issues that the Polish electricity market will have to face, the instrument discussed in this paper may serve as an example of a relatively successful remedy. The real test for the power exchange, which is one of beneficiaries of applying this instrument, will come when the volume of electricity being a subject of the duty is diminished and wholesale energy trading will be subjected to a wider competition between various market places. . Another important test for the instrument we have examined in this paper is development of the EU regional markets that is a process that will significantly change rules of the game in the wholesale energy markets in the EU.

\section{References}

A letter of EFET to the Minister of Economy (2008.12.17), available at: http: / / www.toe.pl/pl/ wybrane-dokumenty/ rok-2008

Act of 29 of June 2007 on Coverage of Generator's Costs Resulting from the Early Termination of Long-Term Power and Electricity Contracts. Journal of Laws 2007, No. 52, item 343, as amended.

Act of 10 of April 1997 on Energy Law; Unified version: Journal of Laws from 2012, Item 1059, as amended (Energy Law).

Ausubel, L. M., Cramton, P., 2010. Virtual Power Plant Auctions. Utilities Policy 18, 201-208.

Bellantuono, G., 2009. Contract Law, Regulation and Competition in Energy Markets. Competition and Regulation Network Industries 10, $159-189$.

Bobinaite, V., Juozapaviciene, A., Staniewski, M., Szczepankowski, P., 2013. Comparative Analysis of Features of Polish and Lithuanian Day-ahead Electricity Market Prices. Energy Policy 63 , 181-196.

Bunn, D., Koc, V., Sapio, A., 2015. Resource Externalities and the Persistence of Heterogeneous Pricing Behavior in an Energy Commodity Market. Energy Economics 48, 265-275.

Cabau, E., 2010. National Regulatory Authorities, in: Jones C., EU Energy Law. The Internal Energy Market - the Third Liberalisation Package, $6.1-6.111$.

Chaton, C., Gasmi, F., Guillerminet, M.L., Oviedo, J.D., 2010. Gas Release and Transport Capacity Investment as Instruments to Foster Competition in Gas Markets. IDEI Working Papers 647, Institut d'Économie Industrielle (IDEI).

Commission Staff Working Paper Interpretative Note on Directive 2009/72/EC Concerning Common Rules for the Internal Market in 
Electricity and Directive 2009/73/EC Concerning Common Rules for the Internal Market in Natural Gas. Regulatory Authorities, 2010.

Directive 2009 / 72 / EC of the European Parliament and of the Council of 13 July 2009 Concerning Common Rules for the Internal Market in Electricity and Repealing Directive 2003/54/ EC; OJ L 211, 2009.

Directive 2009/73/ EC of the European Parliament and of the Council of 13 July 2009 Concerning Common Rules for the Internal Market in Natural Gas and Repealing Directive 2003/55/EC; OJ L 211,2009.

Energy Statistics 2003-2012, Energy Market Agency, Warsaw.

ERO: 2009. National Report of the President of the Energy Regulatory

Office in Poland, Warsaw, July 2012. (ERO 2009)

ERO: 2010. National Report of the President of the Energy Regulatory Office in Poland, Warsaw, July 2012. (ERO 2010)

ERO: 2012. National Report of the President of the Energy Regulatory Office in Poland, Warsaw, July 2012. (ERO 2012)

ERO 2013: National Report of the President of the Energy Regulatory Office in Poland, Warsaw, July 2013. (ERO 2013)

Frontier Economics, 2005. Regulation of Power Exchanges, A Report

Prepared for DTE Energy, available at: https: / / www.acm.nl/nl/ download/ bijlage / ?id=8273

Graf, Ch., Wozabal, D., 2013. Measuring Competitiveness of the EPEX Spot Market for Electricity. Energy Policy 62, 948-958.

Grudziński, Z., 2010. Competitiveness of Brown and Hard Coal-based Power Generation. Polityka Energetyczna - Energy Policy Journal 13, 157-171.

Kamiński, J., 2012. The Development of Market Power in the Polish Power Generation Sector: A 10-year perspective. Energy Policy 42, 136-147.

Kamiński, J., 2009. The Impact of Liberalisation of the Electricity Market on the Hard Coal Mining Sector in Poland. Energy Policy 37, 925-939.

Kamiński, J., 2011. Market Power in a Coal-based Power Generation Sector: the Case of Poland. Energy 36, 6634-6644.

Kamiński, J., Kudełko, M., 2010. The Prospects for Hard Coal as a Fuel for the Polish Power Sector. Energy Policy 38, 7939-7950.

Kloc-Evison, K., Kośka, D., 2010. Rozwój Konkurencji i Przeciwdziałanie Negatywnym Skutkom Naturalnych Monopoli, in: M. Swora, Z. Muras (ed.), Prawo Energetyczne - Komentarz, Wolters Kluwer Polska, 105-131. 
Konin Aluminium Plant:

https: / pl.wikipedia.org/wiki/Huta_Aluminium_Konin

Meeus, L., 2011. Why (and How) to Regulate Power Exchanges in the EU Market Integration Context? Energy Policy 39, 1470-1475.

Meeus, L., Vandezande, L., Cole, S., Belmans, R., 2009. Market Coupling and the Importance of Price Coordination Between Power Exchanges. Energy 34, 228-234.

Muras, Z., Elżanowski, F., 2010. Komentarz do art. 49a, in. M. Swora, Z. Muras (ed.), Prawo Energetyczne - Komentarz. Wolters Kluwer Polska, 128 - 1282.

Nakajima, T., 2013. Inefficient and Opaque Price Formation in the Japan Electric Power Exchange. Energy Policy 55, 329-334.

Pollitt, M. G., 2012. The Role of Policy in Energy Transitions: Lessons from the Energy Liberalisation Era. Energy Policy 50, 128-137.

POLPX Web Page: http: / / www.polpx.pl/en/103/misja-i-zakres-dzialalnosci-tge (POLPX)

Posner, R.,1981. The Economics of Justice. Harvard University Press.

Schultz, C., 2005. Virtual Capacity and Competition, CESifo Working Paper No. 1487, University of Copenhagen.

Singh, A., 2010. Towards a Competitive Market for Electricity and Consumer Choice in the Indian Power Sector. Energy Policy 38, 41964208.

Spanjer, A., 2009. Long-Term Contracts And Competition On European Gas Markets - Has The Commission Struck The Right Balance? Competition and Regulation Network Industries 10, 189 - 205.

Stelmach, J., Brożek, B., 2006. Methods of Legal Reasoning. Wolters Kluwer Polska.

Summary of Commission Decision of 11 October 2007 Relating to a Proceeding Pursuant to Article 82 of the EC Treaty (Case COMP / B-1/37.966 - Distrigas) OJ C 9/8 of 15.1.2008

Swora, M., 2013. Działalność Przedsiębiorstw Energetycznych (Wybrane Obowiązki), in: Grabowski J., Kieres L., Walaszek-Pyzioł A., System Prawa Administracyjnego 8b. Publiczne Prawo Gospodarcze. C.H. Beck, 231 - 244. 
Swora, M., 2013. Krajowe Organy Regulacyjne w Trzecim Pakiecie Liberalizacyjnym, in: Rudnicki, M., Sobieraj, K. (red.), Nowe Prawo Energetyczne. Wydawnictwo KUL, 97 - 108.

Tajana, A., 2006. If I Had a Hammer... Structural Remedies and Abuse of Dominant Position. Competition and Regulation Network Industries 7, $3-29$.

TOE Report, 2012. Electricity Market in Poland: Status on 31 March, Warsaw.

Wach, M., 2011. Polish Telecom Regulator's Decisions Regarding Mobile Termination Rates and the Standpoint of the EC. Yearbook of Antitrust and Regulatory Studies, 111-132. 